\title{
11. BIOMARKER AND PYROLYSIS GEOCHEMISTRY OF ORGANIC MATTER FROM ARGO AND GASCOYNE ABYSSAL PLAIN SEDIMENTS, NORTHEASTERN INDIAN OCEAN ${ }^{1}$
}

\author{
D. T. Heggie, ${ }^{2}$ C. J. Boreham, ${ }^{2}$ and R. E. Summons ${ }^{2}$
}

\begin{abstract}
The sediments of the Argo and Gascoyne abyssal plains are generally lean in organic matter, are immature, and contain hydrocarbons trapped during sediment deposition rather than those generated during sediment catagenesis.

TOC concentrations in the Argo Abyssal Plain Cenozoic sediments are $0.5 \mathrm{wt} \%$, and organic matter appears to be from mixed marine and reworked, degraded, organic matter sources, with the latter being contributed by turbidity flows from the nearby continental margin. TOC concentrations within the Cenozoic sediments of the Gascoyne Abyssal Plain are mostly undetectable $(<0.1 \mathrm{wt} \%)$.

Biomarker distributions determined by gas chromatography (GC) and gas chromatography-mass spectrometry (GCMS) indicate that organic matter extracted from the Lower Cretaceous sediments from both sites is predominantly marine with varying contributions from terrestrial organic matter. The specific marine biomarker, 24- $n$-propylcholestane is in relatively high abundance in all samples. In addition, the relatively high abundance of the 4-methylsteranes with the 23 , 24-dimethyl side chain (in all samples) indicates significant dinoflagellate contributions and marine organic matter.

The ratios of $n-\mathrm{C}_{27} / n-\mathrm{C}_{17}$ reflect relative contributions of marine vs. terrestrial organic matter. TOC, while generally low at Argo, is relatively high near the Barremian/Aptian boundary (one sample has a TOC of 5.1 wt\%) and the Aptian/Albian boundary (up to $1.3 \mathrm{wt} \% \mathrm{TOC}$ ), and two samples from the Barremian and Aptian sections contain relatively high proportions of terrestrial organic carbon. TOC values in the Lower Cretaceous sediments from Gascoyne Abyssal Plain are low $(<0.1 \mathrm{wt} \%)$ near the Aptian/Barremian boundary. TOC values are higher in older sediments, with maxima in the upper Barremian (1.02 wt \%), the Barremian/Hauterivian $(0.6 \mathrm{wt} \%)$, and Valanginian $(1.8 \mathrm{wt} \%)$. Sediments from the upper Barremian contain higher amounts of terrestrial organic carbon than older sediments.
\end{abstract}

\section{INTRODUCTION}

The formation of the modern Indian Ocean, including the Argo and Gascoyne Abyssal Plains, off northwestern Australia (Fig. 1), began with Late Jurassic to Early Cretaceous rifting along the northern and western margins (Ludden, Gradstein et al., 1990). Geohistory analysis of the nearby DSDP Site 261 in the Argo Abyssal Plain indicates an initial water depth of around $2.5 \mathrm{~km}$. Rapid cooling and subsidence resulted in a water depth near 4000 $\mathrm{m}$ during the Hauterivian/Barremian. Slower subsidence through the Late Cretaceous and Cenozoic resulted in a present-day water depth near $5700 \mathrm{~m}$ (Ludden, Gradstein et al., 1990). The Gascoyne Abyssal Plain (Site 766, Fig. 1) is near the foot of the Exmouth Plateau escarpment. Subsidence and sedimentation considerations indicate this site originated at a water depth near $800 \mathrm{~m}$; rapid subsidence in the Early Cretaceous brought the site near to its present water depth of $4000 \mathrm{~m}$.

The sediments at the Argo and Gascoyne abyssal plains began to be deposited during the Early Cretaceous with the onset of seafloor spreading. About $935 \mathrm{~m}$ of sediment was cored at Site 765 (Argo), and approximately $500 \mathrm{~m}$ of these sediments are Lower Cretaceous calcareous claystones and hemipelagic clays that accumulated at rates of about 5 meters per million years $(\mathrm{m} / \mathrm{Ma})$ during Valanginian through Barremian time, $14 \mathrm{~m} / \mathrm{Ma}$ during the Aptian, and $4.2 \mathrm{~m} / \mathrm{Ma}$ during the Albian (Ludden, Gradstein, et al., 1990). Site 765 has remained close to or below the CCD. Some turbidite deposition is evident in the Lower Cretaceous sequence. Late Cretaceous and Paleogene sedimentation rates were low $(<2 \mathrm{~m} / \mathrm{Ma})$, and the appearance of siliciclas-

\footnotetext{
${ }^{1}$ Gradstein, F. M., Ludden, J. N., et al., 1992. Proc ODP, Sci. Results, 123: College Station, TX (Ocean Drilling Program).

2 Bureau of Mineral Resources, Division of Marine Geosciences and Petroleum Geology, P.O. Box 378, Canberra, ACT, 2601, Australia.
}

tic and calcareous turbidites in the Upper Cretaceous to Paleogene sequence indicates a change from primarily hemipelagic to turbidite-dominated sedimentation. Turbidites dominate the Cenozoic; Neogene sedimentation rates were estimated at near $26 \mathrm{~m} / \mathrm{Ma}$.

About $467 \mathrm{~m}$ of sediment was cored at Gascoyne Abyssal Plain (Site 766), of which approximately $300 \mathrm{~m}$ accumulated during the Early Cretaceous. Sedimentation rates decreased from the Valanginian ( $60 \mathrm{~m} / \mathrm{Ma}$ ) through the Aptian/Albian (3.2 m/Ma). Lower Cretaceous sediments are greenish-gray to dark-green and black clay, sand, and siltstones. A marked change occurs near the Aptian/Barremian boundary from deposition of hemipelagic, terrigenous, and shallow-water marine sediments to hemipelagic and pelagic calcareous sediments. Site 766 has remained above the calcite compensation depth (CCD; Ludden, Gradstein, et al., 1990).

This study describes the results of organic biomarker and pyrolysis geochemistry conducted in the Bureau of Mineral Resources (BMR) laboratories. These laboratory data have been integrated with the Rock-Eval data obtained on board the JOIDES Resolution to help elucidate the nature of the depositional environments of the deep-water Argo and Gascoyne abyssal plain drill sites. Biomarker and combined pyrolysis data were used to investigate: (1) the source (i.e., marine and/or terrestrial) of the organic matter in the sediments and, (2) the variations in source through time. The focus is on the Lower Cretaceous sediments. RockEval, $\mathrm{T}_{\max }$ values, and some biomarker maturity parameters were used to assess the thermal maturation levels of the organic matter.

\section{METHODS}

Thirty sediment samples selected for analyses at the BMR were first screened by Rock-Eval pyrolysis. These data are summarized in Table 1. Eleven samples were then soxhlet-extracted with solvent $\left(\mathrm{CHCl}_{3}: \mathrm{MeOH}: 87: 13\right)$ for $48 \mathrm{hr}$. Column chromatography of the extract on silica gave saturates, aromatics, and the polar (NSO) fraction (Powell, 1982). Seven saturated hydrocar- 


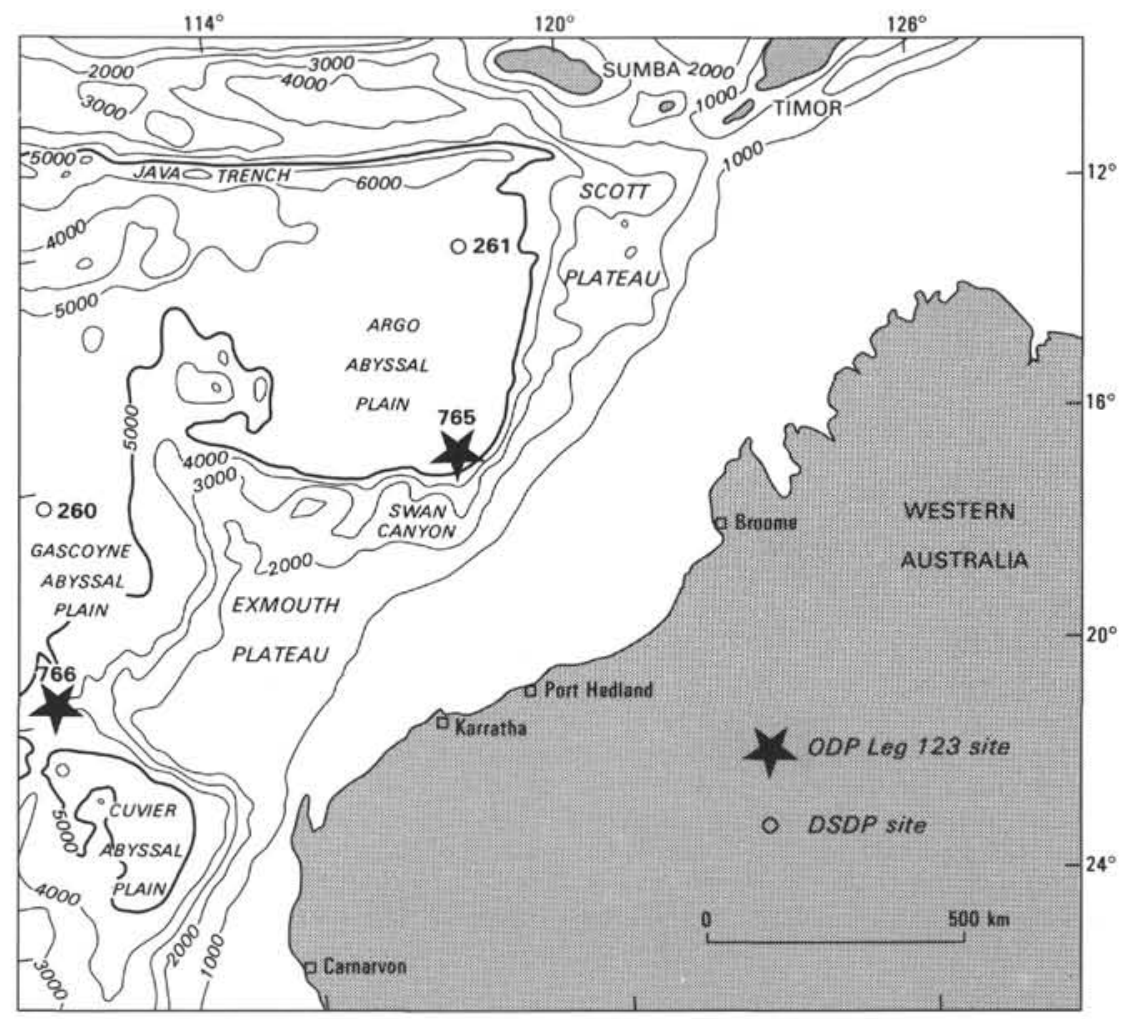

Figure 1. Map of the continental margin of northwestern Australia showing drill Sites 765 (Argo Abyssal Plain) and 766 (Gascoyne Abyssal Plain).

Table 1. Rock-Eval pyrolysis data from BMR.

\begin{tabular}{|c|c|c|c|c|c|c|c|}
\hline $\begin{array}{l}\text { Core, section, } \\
\text { interval, (cm) }\end{array}$ & Age & $\begin{array}{c}\text { TOC } \\
\text { (wt\%) }\end{array}$ & $\begin{array}{l}\mathrm{T}_{\max } \\
\left({ }^{\circ} \mathrm{C}\right)\end{array}$ & $S_{1}$ & $\mathrm{~S}_{2}$ & PI & HI \\
\hline \multicolumn{8}{|l|}{ 123- } \\
\hline $765 \mathrm{~B}-03 \mathrm{H}-3,8-16$ & $\mathrm{P}$ & 0.54 & 545 & 0.35 & 1.53 & 1.81 & 283 \\
\hline $765 C-35 R-3,60-69$ & Ap & 0.35 & 494 & 0.00 & 1.41 & 0.00 & 403 \\
\hline $765 C-44 R-3,42-50$ & Ap & 1.23 & 417 & 0.19 & 1.23 & 0.13 & 100 \\
\hline $765 C-44 R-5,2-10$ & Ap & 0.40 & 470 & 0.00 & 1.23 & 0.00 & 308 \\
\hline $765 \mathrm{C}-49 \mathrm{R}-1,96-104$ & B & 0.55 & 541 & 0.10 & 1.11 & 0.08 & 202 \\
\hline $766 \mathrm{~A}-27 \mathrm{R}-2,66-68$ & B & 0.14 & 355 & 0.13 & 0.19 & 0.41 & 136 \\
\hline $766 \mathrm{~A}-28 \mathrm{R}-6,106-109$ & B & 0.30 & 354 & 0.07 & 0.27 & 0.21 & 90 \\
\hline $766 \mathrm{~A}-29 \mathrm{R}-4,89-95$ & B & 0.33 & 454 & 0.10 & 0.52 & 0.16 & 158 \\
\hline $766 \mathrm{~A}-30 \mathrm{R}-4,48-54$ & B & 0.59 & 337 & 0.10 & 0.25 & 0.00 & 42 \\
\hline $766 \mathrm{~A}-30 \mathrm{R}-1,140-150$ & B & 0.61 & 414 & 0.04 & 0.61 & 0.06 & 100 \\
\hline $766 \mathrm{~A}-31 \mathrm{R}-1,58-64$ & B & 0.70 & 416 & 0.14 & 0.66 & 0.17 & 94 \\
\hline $766 \mathrm{~A}-31 \mathrm{R}-2,145-150$ & B & 0.78 & 420 & 0.13 & 0.62 & 0.18 & 79 \\
\hline $766 \mathrm{~A}-32 \mathrm{R}-4,132-138$ & $\mathrm{~B} / \mathrm{H}$ & 1.02 & 421 & 0.181 & 0.77 & 0.19 & 75 \\
\hline $766 \mathrm{~A}-33 \mathrm{R}-3,42-50$ & $\mathrm{H}$ & 0.34 & 385 & 0.05 & 0.37 & 0.12 & 109 \\
\hline $766 \mathrm{~A}-34 \mathrm{R}-1,69-75$ & $\mathrm{H}$ & 0.27 & 334 & 0.07 & 0.35 & 0.17 & 130 \\
\hline $766 \mathrm{~A}-36 \mathrm{R}-1,122-127$ & H & 0.25 & 362 & 0.29 & 0.51 & 0.36 & 204 \\
\hline $766 \mathrm{~A}-37 \mathrm{R}-1,59-65$ & H & 0.42 & 379 & 0.24 & 0.58 & 0.29 & 138 \\
\hline $766 \mathrm{~A}-38 \mathrm{R}-3,98-104$ & $\mathrm{H}$ & 0.68 & 339 & 0.29 & 0.49 & 0.37 & 72 \\
\hline $766 \mathrm{~A}-39 \mathrm{R}-2,114-122$ & $\mathrm{H}$ & 0.53 & 383 & 0.29 & 0.58 & 0.34 & 109 \\
\hline $766 \mathrm{~A}-40 \mathrm{R}-3,44-51$ & $\mathrm{H}$ & 0.44 & 358 & 0.33 & 0.58 & 0.37 & 132 \\
\hline $766 \mathrm{~A}-41 \mathrm{R}-4,82-87$ & $\mathrm{H}$ & 0.51 & 370 & 0.28 & 0.57 & 0.33 & 112 \\
\hline $766 \mathrm{~A}-42 \mathrm{R}-4,100-108$ & $\mathrm{H}$ & 0.51 & 371 & 0.22 & 0.54 & 0.29 & 106 \\
\hline $766 \mathrm{~A}-43 \mathrm{R}-4,97-105$ & $\mathrm{H}$ & 0.36 & 389 & 0.22 & 0.63 & 0.26 & 175 \\
\hline $766 \mathrm{~A}-43 \mathrm{R}-4,114-119$ & $\mathrm{H}$ & 0.53 & 377 & 0.21 & 0.59 & 0.26 & 111 \\
\hline $766 \mathrm{~A}-44 \mathrm{R}-6,5-11$ & $\mathrm{H}$ & 0.49 & 410 & 0.24 & 0.80 & 0.23 & 163 \\
\hline $766 \mathrm{~A}-45 \mathrm{R}-4,98-106$ & H & 1.25 & 424 & 0.33 & 1.27 & 0.21 & 102 \\
\hline $766 \mathrm{~A}-46 \mathrm{R}-6,50-57$ & $\mathrm{~V}$ & 0.73 & 422 & 0.21 & 0.61 & 0.26 & 84 \\
\hline $766 \mathrm{~A}-47 \mathrm{R}-4,95-102$ & $\mathrm{v}$ & 0.68 & 403 & 0.21 & 0.65 & 0.24 & 96 \\
\hline $766 \mathrm{~A}-48 \mathrm{R}-4,16-18$ & $\mathrm{v}$ & 0.50 & 395 & 0.15 & 0.70 & 0.18 & 140 \\
\hline $766 \mathrm{~A}-49 \mathrm{R}-3,47-51$ & $\mathrm{v}$ & 0.71 & 399 & 0.27 & 0.88 & 0.24 & 124 \\
\hline
\end{tabular}

Age: $\mathrm{P}=$ Pleistocene, $\mathrm{Ap}=$ Aptian, $\mathrm{B}=$ Barremian, $\mathrm{B} / \mathrm{H}=$ Barremian/Hauterivian, $\mathrm{V}=$ Valanginian. $\mathrm{S}_{1}, \mathrm{~S}_{2}$ in $\mathrm{mg} \mathrm{HC} / \mathrm{g} ; \mathrm{PI}$ and $\mathrm{HI}$ in $\mathrm{mg} \mathrm{HC} / \mathrm{g}$ organic $\mathrm{C}$. 
bon fractions were then analyzed for a variety of biomarkers by combined gas chromatography-mass spectrometry (Summons et al., 1988).

\section{TOTAL ORGANIC CARBON DISTRIBUTIONS, PYROLYSIS, AND SOURCE CHARACTERISTICS}

\section{Argo Abyssal Plain}

Shipboard total organic carbon (TOC) data from the Argo Abyssal Plain are summarized in Figure 2. Four additional samples were selected from the Lower Cretaceous sediments of Site 765 of Aptian through Barremian age, while one sample was taken from the Pleistocene section (BMR Rock-Eval data shown in open circles). The TOC values from these additional analyses (Table 1) vary between 0.4 and $1.3 \mathrm{wt} \%$ and are similar to those found from the shipboard analyses.

\section{Argo Abyssal Plain (Cenozoic Sediments)}

TOC data from the Cenozoic sediments are highest in the top 50 mbsf (up to $1.5 \mathrm{wt} \%$ ), and decrease with increasing depth, although the data show large concentration differences over short distances. These sediments are dominated by turbidite deposition (Ludden, Gradstein, et al., 1990). Calcium carbonate and TOC data from a single turbidite are shown in Figure 3. Calcium carbonate data are lowest in the top of the turbidite, probably because of dissolution in corrosive bottom waters below the CCD. TOC concentrations vary about tenfold over about $1.5 \mathrm{~m}$ of this turbidite and are lowest at the base of the turbidite in the coarsegrained sediments and highest in the fine-grained sediments toward the turbidite top. These large variations within a single turbidite, over distances of less than $2 \mathrm{~m}$, are comparable to changes in TOC over the whole Cenozoic section and thus explain, in part, TOC variations in the Cenozoic sediments.

Pore water data from this site (Ludden, Gradstein, et al., 1990) show that sulfate decreases with increasing depth in the sediments to near asymptotic concentrations of 6 to $7 \mathrm{mM}$, representing about a $70 \%$ depletion from bottom-water concentrations, at about 300 mbsf. The oxidation and remineralization of buried organic matter, primarily by seawater metabolites, oxygen, nitrate, and sulfate during early diagenesis (e.g., Bender and Heggie, 1984) explains the trend of decreasing TOC with increasing depth of burial. The observed TOC distributions with depth in the Cenozoic sediments of the Argo Abyssal Plain thus result from the combined effects of pelagic and frequent turbidite deposition with a diagenetic overprint.

\section{Rock-Eval Data}

The combined Rock-Eval data sets from Site 765 were screened, and those having $\mathrm{S}_{2}<0.2$ and TOC $<0.5 \mathrm{wt} \%$ were not considered further (the screened Rock-Eval data from shipboard analyses are summarized in Table 2). A cross plot (Peters, 1986) of the hydrogen index (HI) and oxygen index (OI) of Site 765 data is shown in Figure 4. This plot may be used similarly to a van Krevelen diagram to differentiate organic matter types. Because all samples have TOC $<2 \mathrm{wt} \%$ (with one exception) and have variable amounts of calcium carbonate and clay minerals, the pyrolysis yields have probably been suppressed by the mineral matrix effect (Espitalié et al., 1980; Orr, 1983; Katz, 1983; Peters, 1986). This effect results in low, but variable, $\mathrm{HI}$ values compared to results on demineralized organic matter and, hence, introduces artificial differences in organic matter compositions.

The Cenozoic (Fig. 4) samples were from the top $100 \mathrm{mbsf}$ of sediment and are of Pleistocene age. These samples have variable

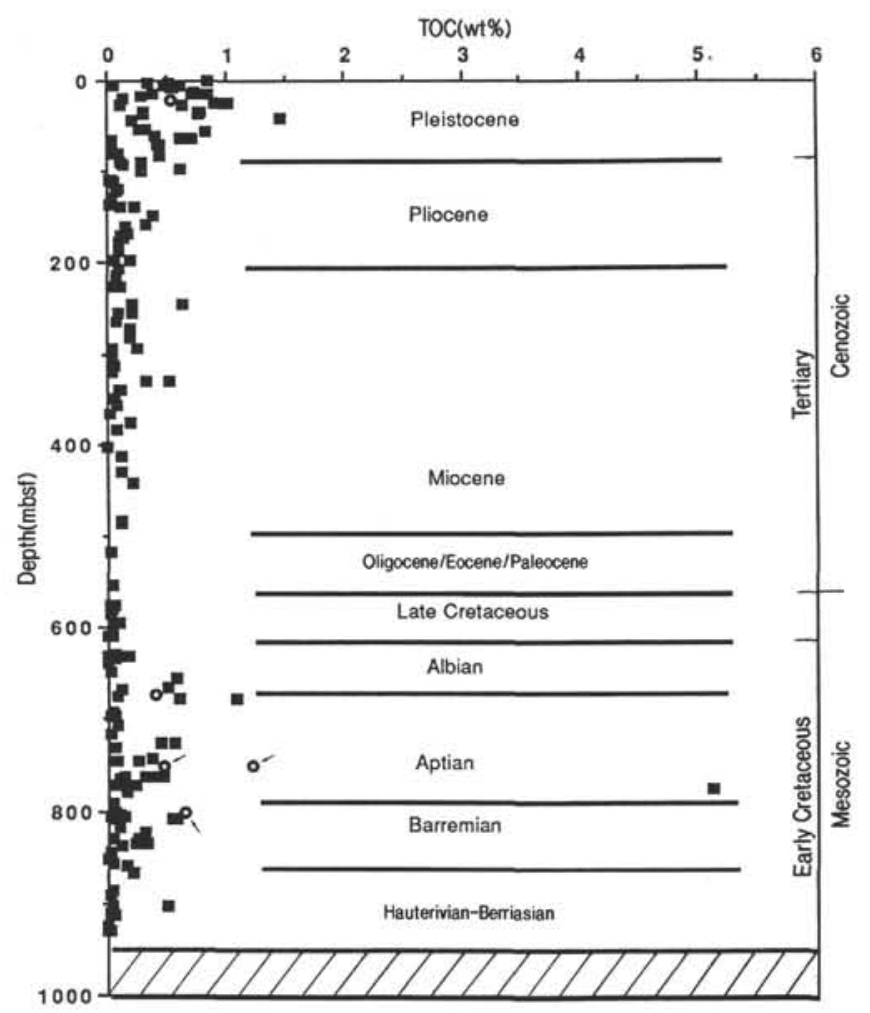

Figure 2. Downhole TOC profile, Site 765 (shipboard Rock-Eval data $=$ closed squares; BMR data = open circles; samples extracted for hydrocarbons are shown with an arrow). 


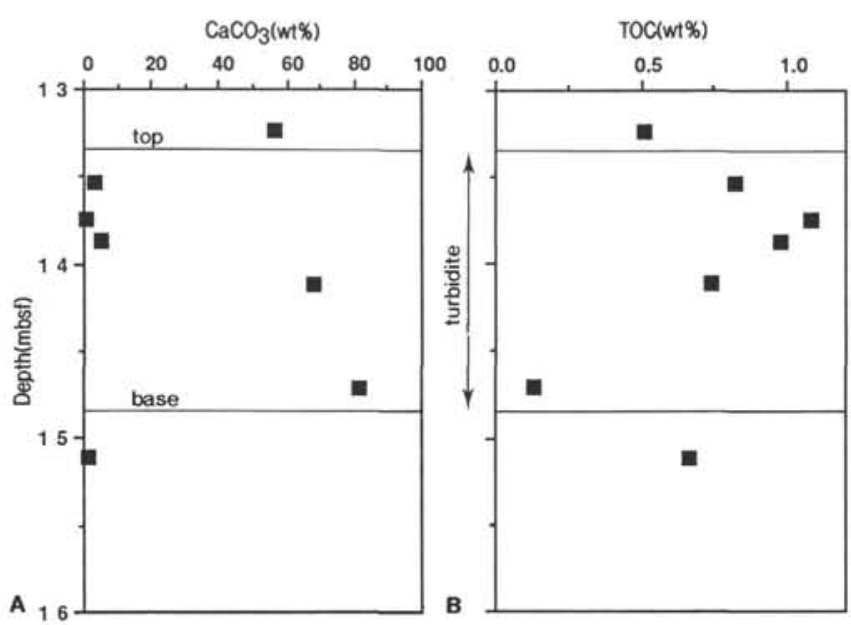

Figure 3. Calcium carbonate and TOC data from a turbidite.

$\mathrm{HI}$ values $(150<\mathrm{HI}<500)$ and plot between the Type II/III mean evolution lines (data not plotted have $\mathrm{HI}<400$ and $\mathrm{OI}>350$ ), suggesting predominantly Type II organic matter, with the variation in HI values probably owing to a variable mineral matrix effect. An additional contribution from varying amounts of hydrogenpoor, reworked organic matter is also likely (see discussion in "Maturity" section, this chapter). Shipboard palynological investigations indicated that samples from Miocene/Pliocene massflow deposits contained reworked Jurassic dinoflagellates, as well as spores and pollen (Ludden, Gradstein, et al., 1990). The variation in OI is more problematic. For example, in the Cretaceous marine Toolebuc Formation (Queensland, Australia), which is Type II organic matter (Boreham and Powell, 1987), oxidation (of the marine organic matter) results in a decrease in $\mathrm{HI}$ with little increase in OI, whereas high $\mathrm{OI}$ and low $\mathrm{HI}$ values were associated with terrestrial organic matter. The trend in the Cenozoic samples in Figure 4 (decreasing $\mathrm{HI}$ with increasing OI) also suggests a combination of varying degrees of oxidation associated with mixed marine and terrestrial sources of organic matter. However, in these organic-lean rocks, a major contribution to the amount of $\mathrm{CO}_{2}$ released is most likely from decomposition of carbonate minerals, which would mask any trend in the data.

\section{Argo Abyssal Plain (Mesozoic Sediments)}

TOC are generally low ( wt \%) in the Mesozoic section. However, isolated samples of higher TOC were occasionally found. The highest TOC was found in an isolated, thin $(1 \mathrm{~cm})$, black sediment layer (123-765C-45R-4, 100-101 cm) near the Barremian/Aptian boundary (Fig. 2). This sediment (Thurow, pers. comm., 1991) was finely laminated and not bioturbated (although adjacent sediments were bioturbated) and was (under the scanning electron microscope) almost entirely framboidal pyrite. These observations and other estimates of the pyrite abundance (Heggie, this volume) suggest that this sediment was deposited during a brief period of anoxia in the overlying water (additional samples for laboratory analyses, however, were not available from this interval). TOC vales near the Aptian/Albian boundary were up to $1.3 \mathrm{wt} \%$ (Fig. 2).

The Mesozoic samples of Site 765, from depths greater than $650 \mathrm{mbsf}$ and representing Lower Cretaceous sediments from Albian through Valanginian/Berriasian ages, have a low HI (75) and cluster about the Type III mean evolution line. These data

Table 2. Selected shipboard Rock-Eval and calcium carbonate data, Site 765.

\begin{tabular}{|c|c|c|c|c|c|c|c|c|c|c|c|c|}
\hline $\begin{array}{l}\text { Core, section, } \\
\text { interval, (cm) }\end{array}$ & $\begin{array}{l}\text { Depth } \\
\text { (mbsf) }\end{array}$ & $\begin{array}{c}\mathrm{CaCO}_{3} \\
(\mathrm{wt} \%)\end{array}$ & $\mathrm{S}_{1}$ & $\mathrm{~S}_{2}$ & $\mathrm{~S}_{3}$ & $\begin{array}{l}\text { TOC } \\
\text { (wt\%) }\end{array}$ & $\begin{array}{l}\mathrm{C} \\
\%\end{array}$ & $\mathrm{HI}$ & OI & $\begin{array}{l}\mathrm{T}_{\max } \\
\left({ }^{\circ} \mathrm{C}\right)\end{array}$ & PI & $\mathrm{S}_{2} / \mathrm{S}_{3}$ \\
\hline \multicolumn{13}{|l|}{$123-$} \\
\hline $765 \mathrm{~B}-1 \mathrm{H}-1,96-98$ & 0.96 & 13.0 & 0.64 & 1.47 & 4.98 & 0.85 & 0.17 & 172 & 585 & 384 & 0.30 & 0.29 \\
\hline $765 \mathrm{~B}-1 \mathrm{H}-2,78-80$ & 2.28 & 52.5 & 0.38 & 1.25 & 5.15 & 0.52 & 0.13 & 240 & 990 & 404 & 0.23 & 0.24 \\
\hline $765 \mathrm{~A}-1 \mathrm{H}-4,38-40$ & 4.88 & 0.4 & 0.68 & 2.76 & 1.05 & 0.61 & 0.28 & 452 & 172 & 490 & 0.20 & 2.62 \\
\hline $765 \mathrm{~B}-1 \mathrm{H}-6,61-63$ & 8.11 & 2.5 & 0.56 & 2.19 & 3.22 & 0.54 & 0.22 & 405 & 596 & 544 & 0.20 & 0.68 \\
\hline $765 \mathrm{~A}-1 \mathrm{H}-6,68-70$ & 8.18 & 72.3 & 0.42 & 1.65 & 4.47 & 0.55 & 0.17 & 300 & 812 & 413 & 0.20 & 0.36 \\
\hline $765 \mathrm{~B}-2 \mathrm{H}-3,65-67$ & 12.95 & 2.9 & 0.46 & 1.65 & 3.55 & 0.74 & 0.17 & 222 & 479 & 517 & 0.22 & 0.46 \\
\hline $765 \mathrm{~B}-2 \mathrm{H}-3,123-135$ & 13.53 & 3.4 & 0.21 & 2.27 & 3.77 & 0.71 & 0.20 & 319 & 530 & 588 & 0.08 & 0.60 \\
\hline $765 \mathrm{~B}-2 \mathrm{H}-3,145-150$ & 13.75 & 0.8 & 0.38 & 2.37 & 1.79 & 0.84 & 0.22 & 282 & 213 & 464 & 0.14 & 1.32 \\
\hline $765 \mathrm{~B}-2 \mathrm{H}-4,7-19$ & 13.87 & 5.4 & 0.22 & 1.39 & 4.76 & 0.84 & 0.13 & 165 & 566 & 544 & 0.14 & 0.29 \\
\hline $765 \mathrm{~B}-2 \mathrm{H}-4,143-150$ & 15.23 & nd & 0.56 & 3.52 & 1.38 & 0.74 & 0.34 & 475 & 186 & 470 & 0.14 & 2.55 \\
\hline $765 \mathrm{~B}-2 \mathrm{H}-4,145-150$ & 15.25 & 0.3 & 0.45 & 3.39 & 1.28 & 0.81 & 0.32 & 418 & 158 & 488 & 0.12 & 2.64 \\
\hline $765 \mathrm{~B}-3 \mathrm{H}-3,145-150$ & 23.25 & 0.4 & 0.54 & 1.56 & 2.43 & 1.03 & 0.17 & 151 & 235 & 407 & 0.26 & 0.64 \\
\hline $765 \mathrm{~B}-3 \mathrm{H}-4,125-128$ & 24.55 & 1.6 & 0.50 & 2.59 & 3.61 & 0.90 & 0.25 & 287 & 401 & 548 & 0.16 & 0.71 \\
\hline $765 \mathrm{~B}-3 \mathrm{H}-4,145-150$ & 24.75 & 0.3 & 0.82 & 3.31 & 2.35 & 1.02 & 0.34 & 324 & 230 & 471 & 0.20 & 1.40 \\
\hline $765 \mathrm{~B}-3 \mathrm{H}-4,145-150$ & 24.75 & 0.3 & 0.63 & 2.55 & 1.16 & 0.92 & 0.26 & 277 & 126 & 504 & 0.20 & 2.19 \\
\hline $765 \mathrm{~B}-3 \mathrm{H}-6,23-26$ & 26.53 & 66.1 & 0.27 & 1.39 & 4.86 & 0.63 & 0.13 & 220 & 771 & 413 & 0.16 & 0.28 \\
\hline $765 \mathrm{~B}-4 \mathrm{H}-4,0-5$ & 33.00 & 0.5 & 0.46 & 4.01 & 0.94 & 0.80 & 0.37 & 501 & 117 & 513 & 0.10 & 4.26 \\
\hline $765 \mathrm{~B}-4 \mathrm{H}-4,0-7$ & 33.00 & 0.5 & 0.40 & 3.99 & 2.63 & 0.78 & 0.36 & 511 & 337 & 468 & 0.09 & 1.51 \\
\hline $765 \mathrm{~B}-4 \mathrm{H}-6,20-22$ & 36.20 & 2.4 & 0.29 & 1.78 & 6.30 & 0.78 & 0.17 & 228 & 807 & 521 & 0.14 & 0.28 \\
\hline $765 \mathrm{~B}-5 \mathrm{H}-2,85-87$ & 40.45 & 31.7 & 0.14 & 0.32 & 4.57 & 1.46 & 0.03 & 21 & 313 & 310 & 0.30 & 0.07 \\
\hline $765 \mathrm{~B}-6 \mathrm{H}-6,99-101$ & 56.29 & 32.7 & 0.06 & 0.37 & 4.53 & 0.83 & 0.03 & 44 & 545 & 417 & 0.14 & 0.08 \\
\hline $765 \mathrm{~B}-7 \mathrm{H}-4,0-7$ & 61.90 & 69.2 & 0.28 & 2.01 & 4.94 & 0.72 & 0.19 & 279 & 686 & 418 & 0.12 & 0.40 \\
\hline $765 \mathrm{~B}-7 \mathrm{H}-4,0-5$ & 61.90 & 69.2 & 0.34 & 1.57 & 2.77 & 0.61 & 0.15 & 257 & 454 & 413 & 0.18 & 0.56 \\
\hline $765 \mathrm{~B}-11 \mathrm{H}-2,19-21$ & 97.69 & 0.6 & 0.17 & 2.35 & 1.31 & 0.62 & 0.21 & 379 & 211 & 474 & 0.07 & 1.79 \\
\hline $765 \mathrm{~B}-35 \mathrm{X}-2,0-5$ & 329.80 & 80.1 & 0.08 & 0.30 & 1.53 & 0.53 & 0.03 & 56 & 288 & 396 & 0.21 & 0.19 \\
\hline $765 \mathrm{C}-33 \mathrm{R}-1,20-21$ & 654.90 & 0.6 & 0.11 & 0.55 & 0.35 & 0.57 & 0.05 & 96 & 61 & 384 & 0.17 & 1.57 \\
\hline $765 C-35 R-3,55-57$ & 677.65 & 6.6 & 0.10 & 0.76 & 2.21 & 1.08 & 0.07 & 70 & 204 & 408 & 0.12 & 0.34 \\
\hline $765 C-35 R-3,86-90$ & 677.96 & 4.7 & 0.07 & 0.32 & 1.51 & 0.59 & 0.03 & 54 & 255 & 398 & 0.18 & 0.21 \\
\hline $765 \mathrm{C}-40 \mathrm{R}-4,149-150$ & 726.89 & 0.7 & 0.13 & 0.50 & 0.75 & 0.55 & 0.05 & 90 & 136 & 517 & 0.21 & 0.66 \\
\hline $765 C-45 R-4,100-101$ & 773.70 & 2.3 & 0.36 & 8.93 & 2.80 & 5.12 & 0.77 & 174 & 54 & 412 & 0.04 & 3.18 \\
\hline $765 C-49 \mathrm{R}-1,94-95$ & 807.24 & 1.1 & 0.01 & 0.43 & 0.33 & 0.57 & 0.03 & 75 & 57 & 399 & 0.02 & 1.30 \\
\hline $765 \mathrm{C}-49 \mathrm{R}-1,141-143$ & 807.71 & 1.0 & 0.02 & 0.55 & 0.51 & 0.54 & 0.04 & 101 & 94 & 398 & 0.04 & 1.07 \\
\hline $765 \mathrm{C}-59 \mathrm{R}-3,149-150$ & 902.39 & 0.6 & 0.16 & 0.63 & 0.08 & 0.51 & 0.06 & 123 & 15 & 373 & 0.21 & 7.87 \\
\hline $765 \mathrm{C}-59 \mathrm{R}-4,111-112$ & 903.51 & 0.5 & 0.18 & 0.66 & 0.06 & 0.50 & 0.07 & 132 & 12 & 369 & 0.21 & 11.00 \\
\hline
\end{tabular}




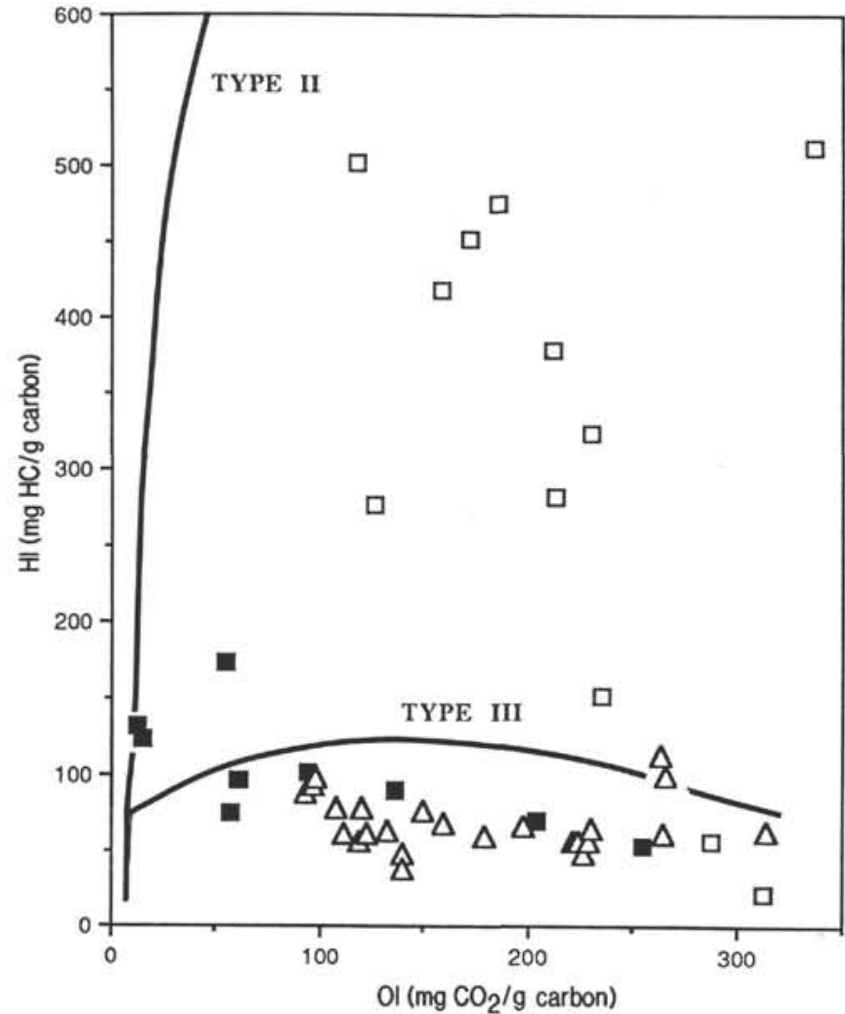

Figure 4. Diagram of Rock-Eval HI vs. OI of Site 765 Cenozoic samples (open squares), Site 765 Mesozoic samples (closed squares), and Site 766 Mesozoic samples (open triangles).

suggest that these samples have a high content of terrestrial organic matter, although the mineral matrix effect (because of the relatively low calcium carbonate and relatively high clay contents) probably results in depressed $\mathrm{HI}$ compared to the Cenozoic samples. The TOC-rich sample $(5.1 \mathrm{wt} \%)$ had the highest HI, but the Rock-Eval data from this and adjacent samples did not provide any clues to changes in the type of organic matter being deposited in the sediments.

\section{Gascoyne Abyssal Plain}

Shipboard TOC data in sediments from the Gascoyne Abyssal Plain are summarized in Figure 5. TOC data from 25 additional samples (open circles) selected from the Lower Cretaceous (Table 1) were similar to shipboard data. TOC was mostly undetectable in the Cenozoic and Upper Cretaceous sediments, but increased in the Lower Cretaceous to concentrations of $1.8 \mathrm{wt} \%$ in samples of Valanginian age. The Rock-Eval data determined aboard the Resolution were screened, and all samples having $\mathrm{S}_{2}<0.2$ and TOC $<0.5 \mathrm{wt} \%$ have been excluded - the remainder are summarized in Table 3. The Mesozoic samples (open triangles) are plotted in Figure 4. All Cenozoic samples failed to provide reliable Rock-Eval parameters and have been excluded. The Cretaceous samples have $\mathrm{HI}$ values of generally $<100$ and variable OI, and contain Type III organic matter similar to that of the Lower Cretaceous sediments from Argo.

\section{GAS CHROMATOGRAPHY AND SOURCE CHARACTERISTICS}

Gas chromatography (GC) analyses of the saturates' extract of all samples showed a homologous series of straight-chained alkanes ranging from $n-\mathrm{C}_{15}$ to $>n-\mathrm{C}_{30}$. Typical GC traces from Early Cretaceous samples (of Aptian age) from Argo (i.e., Sample

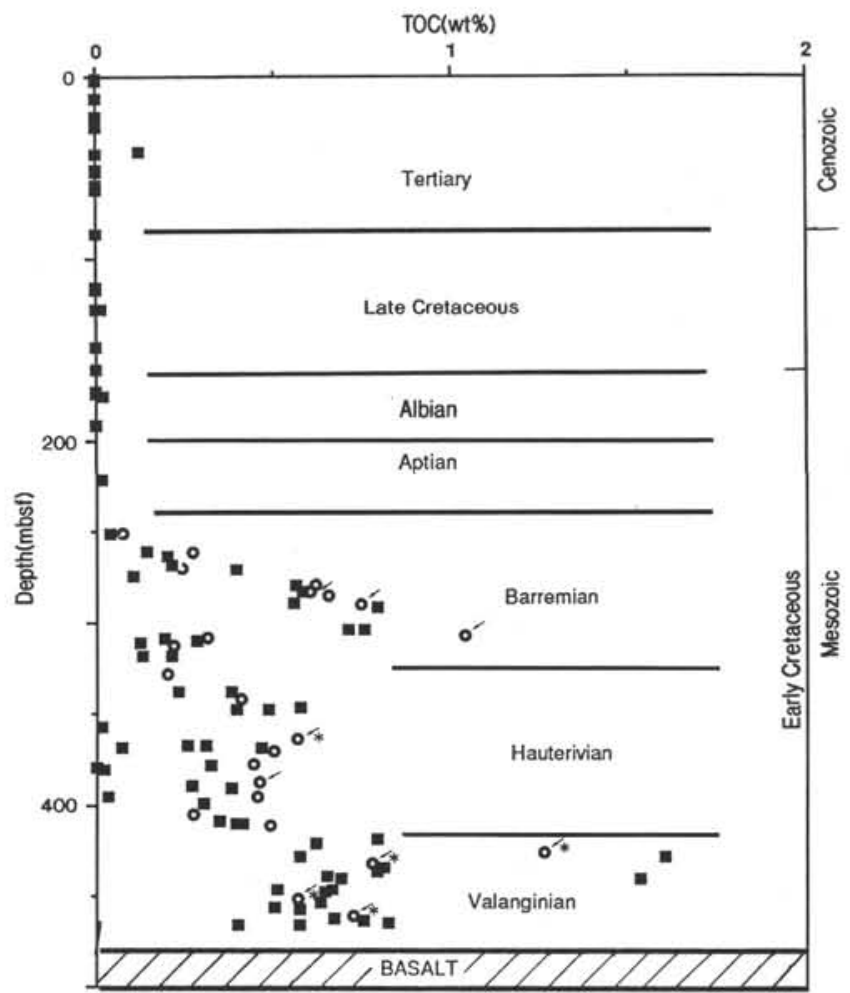

Figure 5. Profile of downhole TOC, Site 766 (shipboard Rock-Eval data $=$ closed squares; BMR data $=$ open circles. Samples extracted for hydrocarbons are shown with an arrow).

123-765C-44R-3, 42-50 cm) and a Valanginian sample from Gascoyne (123-766A-48R-4, 16-18 cm) are shown, respectively, in Figures $6 \mathrm{~A}$ and $6 \mathrm{~B}$. These traces represent the end-member compositions and illustrate the differences between the characteristics of the saturated hydrocarbons at each of these two sites.

Three important features are found in the gas chromatograph (FID) traces. The first relates to the relative proportions of shortand long-chain $n$-alkanes summarized in Table 4 . The ratio of $n-\mathrm{C}_{27} / n-\mathrm{C}_{17}$ may be used as an indicator of the relative contributions of terrestrial and marine organic matter respectively (e.g., Tissot and Welte, 1984). The high $n-\mathrm{C}_{27} / n-\mathrm{C}_{17}$ ratios measured in the relatively thick $(115 \mathrm{~m})$ Aptian (Sample 123-765C-44R-3, $42-50 \mathrm{~cm}$ ) and Barremian $(85 \mathrm{~m})$ sections (Sample 123-765C49R-1, 96-104 cm) from Site 765 indicate high proportions of terrestrial organic matter. Similarly, the high ratios measured in two samples from Site 766 (123-766A-30R-4, 48-54 cm and $123-766-31 \mathrm{R}-2,145-150 \mathrm{~cm}$ ) in dark greenish-gray to black upper Hauterivian and Barremian calcareous claystones indicate a higher proportion of terrestrial organic matter in these samples than in older sediments from Site 766. These observations are consistent with palynological shipboard investigations, which found an abundance of spores and pollen in the high sedimentation rate ( $14 \mathrm{~m} / \mathrm{m} . \mathrm{y}$.) Aptian/Albian sections of Site 765 and also in the $M$. Australis Zone (mostly of Barremian age) of Site 766 (Ludden, Gradstein, et al., 1990).

The second feature of the chromatograms (Fig. 6) is the high proportion of peaks eluting between each alternative $n$-alkane (peaks indicated by an asterisk). Their elution positions and mass spectra suggest that these are homologous series of branched alkanes, but at present, little is known about either their precise structure or their origin. These branched alkanes have different characteristics from the mid-chain monomethyl alkanes that are prominent in many Proterozoic and lower Paleozoic sediments 
Table 3. Selected shipboard Rock-Eval and calcium carbonate data, Site 766.

\begin{tabular}{|c|c|c|c|c|c|c|c|c|c|c|c|c|}
\hline $\begin{array}{c}100 \\
\text { Core, section, } \\
\text { interval }(\mathrm{cm})\end{array}$ & $\begin{array}{l}\text { Depth } \\
\text { (mbsf) }\end{array}$ & $\begin{array}{c}\mathrm{CaCO}_{3} \\
(\mathrm{wt} \%)\end{array}$ & $S_{1}$ & $S_{2}$ & $S_{3}$ & $\begin{array}{c}\text { TOC } \\
\text { (wt\%) }\end{array}$ & $\begin{array}{c}\text { C } \\
(\%)\end{array}$ & $\mathrm{HI}$ & OI & $\begin{array}{l}\mathrm{T}_{\max } \\
\left({ }^{\circ} \mathrm{C}\right)\end{array}$ & P1 & $\mathrm{S}_{2} / \mathrm{S}_{3}$ \\
\hline \multicolumn{13}{|l|}{123} \\
\hline $766 \mathrm{~A}-30 \mathrm{R}-1,140-150$ & 279.30 & 4.1 & 0.06 & 0.56 & 1.49 & 0.56 & 0.05 & 100 & 266 & 436 & 0.10 & 0.37 \\
\hline $766 \mathrm{~A}-31 \mathrm{R}-1,67-70$ & 288.17 & 4.2 & 0.00 & 0.36 & 1.27 & 0.55 & 0.03 & 65 & 230 & 418 & 0.00 & 0.28 \\
\hline 766A-3IR-2, 143-150 & 290.43 & 6.8 & 0.43 & 0.90 & 2.08 & 0.79 & 0.11 & 113 & 263 & 399 & 0.33 & 0.43 \\
\hline $766 \mathrm{~A}-32 \mathrm{R}-4,138-141$ & 303.08 & 3.3 & 0.01 & 0.28 & 1.00 & 0.71 & 0.02 & 39 & 140 & 414 & 0.04 & 0.28 \\
\hline $766 \mathrm{~A}-32 \mathrm{R}-4,143-150$ & 303.13 & 2.8 & 0.09 & 0.67 & 0.70 & 0.75 & 0.06 & 89 & 93 & 411 & 0.12 & 0.95 \\
\hline $766 \mathrm{~A}-37 \mathrm{R}-1,69-70$ & 346.19 & 4.6 & 0.13 & 0.37 & 1.79 & 0.57 & 0.04 & 64 & 314 & 400 & 0.26 & 0.20 \\
\hline $766 \mathrm{~A}-44 \mathrm{R}-4,0-2$ & 417.70 & 5.1 & 0.17 & 0.62 & 0.85 & 0.79 & 0.06 & 78 & 107 & 412 & 0.22 & 0.72 \\
\hline $766 \mathrm{~A}-44 \mathrm{R}-6,15-17$ & 420.85 & 4.3 & 0.01 & 0.41 & 1.23 & 0.62 & 0.03 & 66 & 198 & 416 & 0.02 & 0.33 \\
\hline $766 \mathrm{~A}-45 \mathrm{R}-4,0-2$ & 427.30 & 6.7 & 0.00 & 0.28 & 0.80 & 0.57 & 0.02 & 49 & 140 & 419 & 0.00 & 0.35 \\
\hline $766 \mathrm{~A}-45 \mathrm{R}-4,106-108$ & 428.36 & 5.1 & 0.08 & 1.59 & 1.57 & 1.60 & 0.13 & 99 & 98 & 423 & 0.05 & 1.01 \\
\hline $766 \mathrm{~A}-46 \mathrm{R}-2,0-2$ & 434.04 & 5.1 & 0.00 & 0.50 & 0.90 & 0.81 & 0.04 & 61 & 111 & 419 & 0.00 & 0.55 \\
\hline $766 \mathrm{~A}-46 \mathrm{R}-3,32-34$ & 435.86 & 4.6 & 0.04 & 0.48 & 1.42 & 0.79 & 0.04 & 60 & 179 & 422 & 0.08 & 0.33 \\
\hline $766 \mathrm{~A}-46 \mathrm{R}-4,140-150$ & 438.44 & 4.3 & 0.04 & 0.41 & 0.86 & 0.65 & 0.03 & 63 & 132 & 402 & 0.09 & 0.47 \\
\hline $766 \mathrm{~A}-46 \mathrm{R}-5,141-143$ & 439.95 & 6.5 & 0.06 & 1.20 & 1.84 & 1.53 & 0.10 & 78 & 120 & 422 & 0.05 & 0.65 \\
\hline $766 \mathrm{~A} 46-\mathrm{R}-6,58-59$ & 440.62 & 4.6 & 0.04 & 0.39 & 1.55 & 0.69 & 0.03 & 56 & 224 & 415 & 0.10 & 0.25 \\
\hline $766 \mathrm{~A}-47 \mathrm{R}-3,103-105$ & 446.23 & 5.4 & 0.04 & 0.41 & 1.75 & 0.66 & 0.03 & 62 & 265 & 416 & 0.09 & 0.23 \\
\hline $766 \mathrm{~A}-47 \mathrm{R}-3,148-150$ & 446.68 & 4.9 & 0.01 & 0.29 & 1.17 & 0.51 & 0.02 & 56 & 229 & 409 & 0.03 & 0.24 \\
\hline $766 \mathrm{~A}-47 \mathrm{R}-4,102-104$ & 447.72 & 3.8 & 0.04 & 0.36 & 1.42 & 0.64 & 0.03 & 56 & 221 & 412 & 0.10 & 0.25 \\
\hline $766 \mathrm{~A}-48 \mathrm{R}-1,131-133$ & 453.11 & 3.6 & 0.08 & 0.44 & 1.01 & 0.63 & 0.04 & 69 & 160 & 401 & 0.15 & 0.43 \\
\hline $766 \mathrm{~A}-48 \mathrm{R}-4,16-18$ & 456.46 & 3.3 & 0.05 & 0.33 & 0.99 & 0.50 & 0.03 & 66 & 198 & 330 & 0.13 & 0.33 \\
\hline $766 \mathrm{~A}-48 \mathrm{R}-5,0-2$ & 457.80 & 3.4 & 0.02 & 0.33 & 0.68 & 0.57 & 0.02 & 57 & 119 & 418 & 0.06 & 0.48 \\
\hline $766 \mathrm{~A}-49 \mathrm{R}-1,97-98$ & 462.47 & 1.0 & 0.01 & 0.51 & 1.01 & 0.67 & 0.04 & 76 & 150 & 426 & 0.02 & 0.50 \\
\hline $766 \mathrm{~A}-49 \mathrm{R}-2,0-2$ & 463.00 & 2.3 & 0.04 & 0.71 & 0.72 & 0.75 & 0.06 & 94 & 96 & 596 & 0.05 & 0.98 \\
\hline $766 \mathrm{~A}-49 \mathrm{R}-2,142-143$ & 464.42 & 2.4 & 0.11 & 0.51 & 1.01 & 0.82 & 0.05 & 62 & 123 & 414 & 0.18 & 0.50 \\
\hline $766 \mathrm{~A}-49 \mathrm{R}-4,34-35$ & 466.34 & 1.8 & 0.01 & 0.28 & 1.29 & 0.57 & 0.02 & 49 & 226 & 413 & 0.04 & 0.21 \\
\hline
\end{tabular}

Table 4. Extractable organic matter and gas chromatography analyses.

\begin{tabular}{|c|c|c|c|c|c|}
\hline \multirow[b]{2}{*}{$\begin{array}{l}\text { Core, section, } \\
\text { interval }(\mathrm{cm})\end{array}$} & \multicolumn{3}{|c|}{$\begin{array}{c}\text { Extractable } \\
\text { organic matter }\end{array}$} & \multicolumn{2}{|c|}{$\begin{array}{c}\text { Gas } \\
\text { chromatography }\end{array}$} \\
\hline & Age & $\begin{array}{c}\text { Yield } \\
(\mathrm{ppm})^{\mathrm{a}}\end{array}$ & $\begin{array}{c}\mathrm{mg} \mathrm{HC} / \mathrm{g} \\
\text { rock }\end{array}$ & $\begin{array}{l}n-\mathrm{C} 27 / \\
n-\mathrm{C} 17\end{array}$ & $\mathrm{Pr} / \mathrm{Ph}$ \\
\hline \multicolumn{6}{|l|}{ 123- } \\
\hline $765 C-44 R-3,42-50$ & Ap & 75 & 1.6 & 1.86 & 0.65 \\
\hline $765 \mathrm{C}-49 \mathrm{R}-1,96-104$ & B & 85 & 3.5 & 1.72 & 1.01 \\
\hline $766 \mathrm{~A}-30 \mathrm{R}-4,48-54$ & B & 62 & 5.2 & 1.45 & nd \\
\hline $766 \mathrm{~A}-31 \mathrm{R}-2,145-150$ & B & 182 & 7.8 & 1.57 & 1.00 \\
\hline $766 \mathrm{~A}-32 \mathrm{R}-4,132-138$ & $\mathrm{~B} / \mathrm{H}$ & 184 & 8.6 & 0.75 & 0.81 \\
\hline $766 \mathrm{~A}-38 \mathrm{R}-3,98-104$ & $\mathrm{H}$ & 135 & 2.8 & 1.00 & 0.80 \\
\hline $766 \mathrm{~A}-41 \mathrm{R}-4,82-87$ & $\mathrm{H}$ & 323 & 21.4 & 1.05 & 1.00 \\
\hline $766 A-45 R-4,98-106$ & $\mathrm{H}$ & 238 & 1.8 & 1.17 & 0.93 \\
\hline $766 \mathrm{~A}-47 \mathrm{R}-4,95-102$ & V & 192 & 4.2 & 0.95 & 1.33 \\
\hline $766 \mathrm{~A}-48 \mathrm{R}-4,16-18$ & V & 137 & 9.1 & 0.82 & 1.50 \\
\hline $766 \mathrm{~A}-49 \mathrm{R}-3,47-51$ & V & 125 & 3.5 & 1.37 & 1.43 \\
\hline
\end{tabular}

a Ppm yield of extract per gram rock; $\mathrm{Ap}=\mathrm{Aptian}, \mathrm{B}=$ Barremian, $\mathrm{H}=$ Hauterivian, $\mathrm{V}=$ Valanginian.

and petroleums (Jackson et al., 1986; Klomp, 1986; Summons, 1987; Summons et al., 1988). These unidentified hydrocarbons sometimes appear in samples of sedimentary bitumen that have experienced high degrees of thermal alteration (Summons, unpubl. data, 1990), or in immature, organically lean, oceanic sediments. The former, however, is not consistent with other indicators of the low thermal maturity of samples from both sites. Here, their presence, along with an extensive unresolved complex multiple (UCM) of hydrocarbons, is consistent with a suite of structures that no longer resemble their original biogenic precursors and that might indicate a component of reworked or "background" organic matter. Gough and Rowland (1990) showed by chemical degradation that the UCM (hump) owes its appearance to a multiplicity of unnaturally branched structures. Their high relative

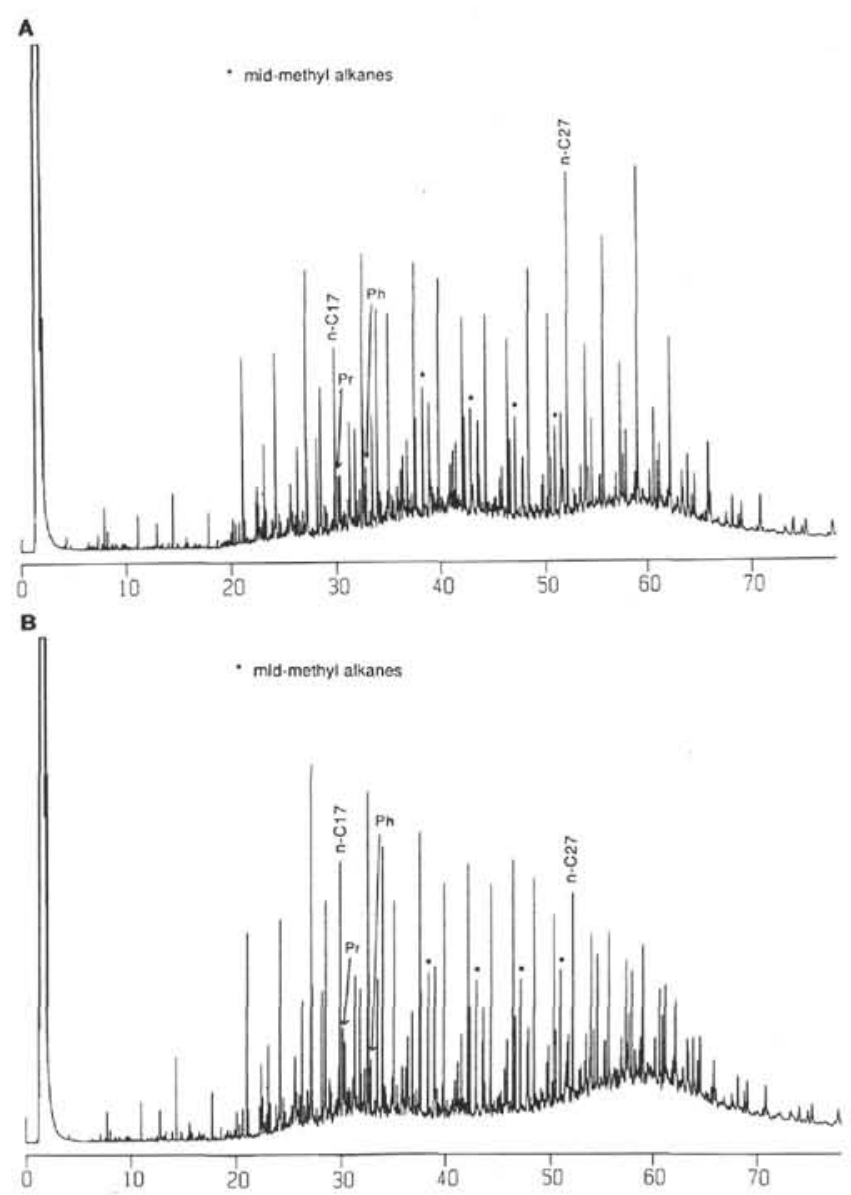

Figure 6. Representative GC traces of (A) a sample of Aptian age from Site 765 and (B) a sample of Valanginian age from Site 766. 
abundance here would result from the fact that little or no hydrocarbon has been generated by catagenesis of in-situ kerogen.

Finally, the two major acyclic isoprenoid hydrocarbons in all the samples are pristane and phytane. Empirical observations of marginally mature to mature rocks suggest that the ratios of pristane to phytane vary systematically according to the type of depositional environment (Powell and McKirdy, 1973). However, the exact reasons for this are currently subject to some controversy (see reviews by Volkman and Maxwell, 1986; ten Haven et al., $1985,1987,1988)$. The sources of pristane and phytane are multiple and complex, but as a general rule, $\mathrm{Pr} / \mathrm{Ph}$ values $>3$ are typical of organic matter having predominantly terrestrial sources deposited in, or transported through, an oxic environment. Values of less than 1 are typically found in sediments from anoxic marine or hypersaline depositional environments. Because pristane/phytane ratios are only reliable indicators of source environment in marginally mature to mature rocks, the immaturity of all Mesozoic samples from both sites (see below) and the fact that $\mathrm{Pr} / \mathrm{Ph}$ ratios mostly fall between 1 and 3 preclude a definitive interpretation of the ratios summarized in Table 4 and, therefore, of depositional environment and occurrences of anoxic/oxic conditions (Powell, 1988).

Interpretations of biomarker ratios, such as $\mathrm{Pr} / \mathrm{Ph}$ and others (see below), to infer the depositional setting and sources of organic carbon must be made cautiously and in consideration of other known information. In this case, the indicators of low maturity tell us that only a minor proportion of the organic carbon has been converted to hydrocarbon. As such, these hydrocarbons may not be representative of the whole suite of organic matter types, because thermally stable kerogen will only release diagnostic markers at higher levels of maturation. Hence, the source-related biomarkers that we identified can indicate that contributions of different types exist, but cannot be used to define accurately the quantitative relationships of these contributions.

\section{GC-MS AND SOURCE-RELATED BIOMARKERS}

Information regarding source type sometimes may be obtained from the relative abundance of $\mathrm{C}_{27}: \mathrm{C}_{28}: \mathrm{C}_{29}$ sterols or their fossil counterparts, the steranes (Huang and Meinschein, 1979; Shi et al., 1982). Land plant influxes usually result in a dominance of $\mathrm{C}_{29}$ desmethylsteranes, whereas in predominantly marine sediments, different types and proportions of algal to zooplankton sources can result in a wide variety of sterane distributions (Seifert and Moldowan, 1978; Mackenzie et al., 1982; Volkman, 1986). Geological age also may be an important consideration
(Grantham, 1986; Grantham and Wakefield, 1988) when assessing the $\mathrm{C}_{27} / \mathrm{C}_{29}$ parameter. The lower $\mathrm{C}_{27} / \mathrm{C}_{29}$ ratios for the Barremian/Hauterivian through Valanginian sediments of Site 766, compared with the Aptian and Barremian sediments of Site 765 (Table 5, Col. 1), suggest an increased terrestrial influence in the Valanginian sediments of Site 766. However, this is contrary to the $n$-alkane distribution (Table 4) and highlights the difficulties for attributing specific sources to the desmethylsteranes (Volkman, 1988). In this case, we suggest that the $n$-alkane distributions better reflect the terrestrial influxes. The presence and high relative abundance of the specific $\mathrm{C}_{30}$ sterane, 24- $n$-propylcholestane, is a reliable marine marker (Moldowan et al., 1985, 1990). Its relative abundances here (Table 5, Col. 2) are similar, for example, to the Mesozoic marine Toolebuc Formation (Boreham and Powell, 1987) and other classic marine sediments, such as the Monterey Formation of California, Lower Toarcian of France, and North Sea Kimmeridge Oil Shale (Moldowan et al., 1985; 1990; Summons et al., 1987) and, consequently, indicate a major contribution of organic matter of marine origin to the Argo and Gascoyne abyssal plains.

Methylsteranes are in high abundance relative to their desmethyl counterparts in all samples (Table 5, Col. 3). The 4-methyl substitution in ring- $\mathrm{A}$ is a characteristic of dinoflagellate sterols and suggests that these organisms are the source of the 4-methylsteranes (Whithers, 1983; Rubinstein and Albrecht, 1975; Robinson et al., 1984; Brassell et al., 1987). The presence of the steroid side chain substitution of 24-ethyl, together with four isomers of 23,24 dimethyl for the $\mathrm{C}_{30}$ 4-methylsteranes (Table 5; Col. 4), is a characteristic of marine sediments (Summons et al., 1987). This pattern becomes prominent in the middle Triassic and coincides with the first appearance in marine sediments of dinoflagellate cysts (Thomas et al., 1990). In nonmarine sediments of equivalent age, only the 24-ethyl side-chain substitution pattern is found in 4-methylsteranes (Summons et al., 1987). The higher relative abundance of the 24-ethyl to the 23,24 dimethyl side chain (dinosterane) (Table 5; Col. 4) in the Aptian and upper Barremian sediments from Argo may reflect subtle compositional differences between dinoflagellate lipid influxes. Two additional series of methylsteranes, $2 \alpha$-methyl and $3 \beta$-methyl ring-A substitution, were observed together in near equal concentrations as their 4-methyl isomers (Table 5; Col. 5). Some evidence exists to suggest that the occurrence of 2- and 3-methylsteranes is associated with bacterial activity during early diagenesis (Summons and Capon, 1988). This appears to be true for the present sample set. The Aptian and upper Barremian sediments from Argo, which

Table 5. Gas chromatography and mass spectrometry source-dependent biomarker parameters.

\begin{tabular}{|c|c|c|c|c|c|c|c|c|c|c|}
\hline $\begin{array}{l}\text { Core, section, } \\
\text { interval }(\mathrm{cm})\end{array}$ & $\begin{array}{l}\mathrm{C}_{27} \mathrm{Ster}^{\mathrm{a}} \\
\mathrm{C}_{29} \text { Ster }\end{array}$ & $\begin{array}{l}\mathrm{C}_{30} \text { Ster }^{\mathrm{b}} \\
\mathrm{C}_{29} \text { Ster }\end{array}$ & $\begin{array}{c}\Sigma \mathrm{C}_{30} \mathrm{Me} \mathrm{Ster}{ }^{\mathrm{c}} \\
\mathrm{C}_{29} \text { Ster }\end{array}$ & $\begin{array}{c}\text { 24-ethyl }{ }^{\mathrm{d}} \\
23,24 \mathrm{DiMe}\end{array}$ & $\begin{array}{l}2 \alpha+3 \beta \mathrm{Me}^{\mathrm{e}} \\
4 \alpha \mathrm{Me} \text { Ster }\end{array}$ & $\begin{array}{c}\Sigma \text { Hop }^{f} \\
\Sigma \text { Ster }\end{array}$ & $\begin{array}{c}2 \alpha \mathrm{Me} \mathrm{Hop} g \\
\text { Hop }\end{array}$ & $\begin{array}{l}29 \mathrm{H}^{\mathrm{h}} \\
\text { Hop }\end{array}$ & $\begin{array}{c}28,30^{j} \\
\text { Hop }\end{array}$ & $\begin{array}{r}28,30^{k} \\
29,30\end{array}$ \\
\hline $765 C-44 R-5,2-10$ & 0.84 & 0.087 & 0.51 & 0.90 & 1.60 & 5.5 & 0.022 & 0.51 & 0.024 & 1.1 \\
\hline $765 \mathrm{C}-49 \mathrm{R}-1,96-104$ & 1.10 & 0.070 & 0.51 & 1.21 & 0.77 & 13.3 & 0.032 & 0.72 & 0.023 & 2.0 \\
\hline $766 \mathrm{~A}-38 \mathrm{R}-3,98-104$ & 0.53 & 0.079 & 0.32 & 0.48 & 0.29 & 2.3 & 0.016 & 0.80 & 0.051 & 2.9 \\
\hline $766 \mathrm{~A}-45 \mathrm{R}-4,98-106$ & 0.52 & 0.120 & 0.44 & 0.48 & 0.51 & 4.7 & 0.012 & 0.27 & 0.024 & 3.2 \\
\hline $766 \mathrm{~A}-47 \mathrm{R}-4,95-102$ & 0.46 & 0.065 & 0.37 & 0.63 & 0.56 & 4.0 & 0.032 & 0.54 & 0.047 & 3.5 \\
\hline $766 \mathrm{~A}-48 \mathrm{R}-4,16-18$ & 0.62 & 0.065 & 0.45 & 0.53 & 0.57 & 3.8 & 0.041 & 0.45 & 0.048 & 2.2 \\
\hline $766 \mathrm{~A}-49 \mathrm{R}-3,47-51$ & 0.45 & 0.110 & 0.48 & 0.58 & 0.53 & 4.1 & 0.029 & 0.51 & 0.044 & 3.0 \\
\hline
\end{tabular}

a $(20 \mathrm{R})-5 \alpha(\mathrm{H}), 14 \alpha(\mathrm{H}), 17 \alpha(\mathrm{H})$-cholestaneC $\left({ }_{27}\right) /(20 \mathrm{R})-24-$ ethyl- $5 \alpha(\mathrm{H}), 14 \alpha(\mathrm{H}), 17 \alpha(\mathrm{H})$-cholestane $\left(\mathrm{C}_{29}\right)$.

b (20R)-24-propyl-5 $\alpha(\mathrm{H}), 14 \alpha(\mathrm{H}), 17 \alpha(\mathrm{H})$-cholestane $\left(\mathrm{C}_{30}\right) /(20 \mathrm{R})$-24-ethyl-5 $\alpha(\mathrm{H}), 14 \alpha(\mathrm{H}), 17 \alpha(\mathrm{H})$-cholestane $\left(\mathrm{C}_{29}\right)$.

c (20R)-2 $\alpha+(20 \mathrm{R})-3 \beta+(20 \mathrm{R})-4 \alpha$-methylsteranes/(20R)-24-ethyl-5 $\alpha(\mathrm{H}), 14 \alpha(\mathrm{H}), 17(\alpha)$-cholestane $\left(\mathrm{C}_{29}\right)$.

d (20R)-4 $\alpha$-methyl-24-ethyl-5 $\alpha(\mathrm{H}), 14 \alpha(\mathrm{H}), 17 \alpha(\mathrm{H})$-cholestane $\left(\mathrm{C}_{30}\right) /(20 \mathrm{R})$-4 $\alpha$-methyl-23,24-dimethyl-5 $\alpha(\mathrm{H}), 14 \alpha(\mathrm{H}), 17 \alpha(\mathrm{H})$-cholestane $\left(\mathrm{C}_{30}\right)$.

e (20R)-2 $\alpha+(20 \mathrm{R})-3 \beta$-methyl-24-ethyl $-5 \alpha(\mathrm{H}), 14 \alpha(\mathrm{H}), 17 \alpha(\mathrm{H})$-cholestane $\left(\mathrm{C}_{30}\right) /(20 \mathrm{R})-4 \alpha$-methylsteranes $\left(\mathrm{C}_{30}\right)$.

f $\Sigma \mathrm{C}_{27}-\mathrm{C}_{34}$ hopanes $/ \Sigma \mathrm{C}_{27}-\mathrm{C}_{30}$ desmethylsteranes.

g $2 \alpha$-methyl-17 $\alpha(\mathrm{H})$-hopane $\left(\mathrm{C}_{31}\right) / 17 \alpha(\mathrm{H}), 21 \beta(\mathrm{H})$-hopane $\left(\mathrm{C}_{30}\right)$.

h $17 \alpha(\mathrm{H}), 21 \beta(\mathrm{H})$-norhopane $\left(\mathrm{C}_{29}\right) / 17 \alpha(\mathrm{H}), 21 \beta(\mathrm{H})$-hopane $\left(\mathrm{C}_{30}\right)$.

j 28,30 bisnorhopane $\left(\mathrm{C}_{28}\right) / 17 \alpha(\mathrm{H}), 21 \beta(\mathrm{H})$-hopane $\left(\mathrm{C}_{30}\right)$.

k 28,30 bisnorhopane $\left(\mathrm{C}_{28}\right) / 29,30$ bisnorhopane $\left(\mathrm{C}_{28}\right)$. 
have the highest relative concentration of hopanes, (Table 5; Col. 6 , an indicator of bacterial activity, see below), also contain more abundant 2- and 3-methylsteranes relative to 4-methylsteranes (Table 5; Col. 5).

A significant and variable bacterial contribution can be seen from the relative abundance of hopanes to steranes (Table 5; Col. 6). The Aptian and upper Barremian samples from Argo contain the highest concentration of hopanes relative to the desmethylsteranes. Sedimentary hopanes are known to be derived from functionalized hopanoids in bacteria (Rohmer et al., 1984; Ourisson et al., 1987), while hopanoids and hopane polyols having an additional methyl substitution at C-2 or C-3 in ring-A have been recognized in several classes of bacteria, such as methylotrophic bacteria and cyanobacteria (Ourisson et al., 1987). Price et al. (1988) and Summons and Jahnke (1990) observed that high relative abundances of methylhopanes (i.e., 2-methylhopanes) in the range $10 \%$ to $20 \%$ of corresponding hopane are characteristic of sediments having high carbonate contents. The relative abundances of 2-methylhopanes in the samples from both sites (Table 5 ; Col. 7) are low and in the range $1.2 \%$ to $4.1 \%$ of the corresponding hopanes. This is consistent with the low carbonate contents, and the ratio of 2-methylhopane/hopane does not vary significantly over the sample set. The ratio of $C_{29}$ hopanes/ $C_{30}$ hopanes (Table 5, Col. 8) is also typical of clastic sediments.

Other distinctive hopanes include the $\mathrm{C}_{28}$ species, 28,30-bisnorhopane, commonly found in marine sediments (e.g., Grantham et al., 1980; Curiale and Odermatt, 1989) and 29,30-bisnorhopane (Summons and Powell, 1987). Both these biomarkers are present in low abundances in all samples (Table 5; Cols. 9 and 10) but their presence, in accord with other source parameters, suggests a marine source for the organic matter. The high relative abundances of bacterial biomarkers is a further illustration of the importance of bacterial contributions to sedimentary organic carbon irrespective of the type and age of the depositional setting.

\section{MATURITY}

Pyrolysis data are summarized in a plot of $T_{\max }$ vs. HI (Fig. 7). The Cenozoic samples appear to separate into two distinct groups: those samples with $\mathrm{T}_{\max }<430^{\circ} \mathrm{C}$ and those greater than $450^{\circ} \mathrm{C}$. The former $T_{\max }$ values suggest that the samples are immature, while the latter indicate mature to over-mature organic matter. However, based upon these limited data, one can see that two carbon sources are contributing to the TOC in these organic-lean sediments. A high proportion of reworked allochthonous organic matter will manifest itself as a high $\mathrm{T}_{\max }$ value, while the immature autoch thonous component is responsible for the consistently high $\mathrm{HI}$ values. Where this latter component is high, a low $\mathrm{T}_{\max }$ also is observed. Based on the $T_{\max }$ values, the organic matter in the Mesozoic samples from both sites is immature

GC analyses of the saturated hydrocarbons indicate that a pronounced odd-to-even predominance exists in the hydrocarbons greater than $\mathrm{C}_{23}$ in all samples, reflecting the immaturity of the sediment with respect to petroleum generation (Tissot and Welte, 1984). The low maturity of the Mesozoic samples, inferred from the Rock-Eval data, also is evident from the biomarker maturity parameters. The original biological configuration (20R in steranes and $22 \mathrm{R}$ in hopanes) is dominant over the more stable (20S and $22 \mathrm{~S}$ ) geological configuration that is present in mature oils and sediments (Tissot and Welte, 1984). Epimer ratios for the steranes and hopanes (Table 6; Cols. 1 and 2, respectively) are far from the equilibrium values that exist within the oil window. Furthermore, the presence of hopanes with the biological $17 \beta(\mathrm{H}), 21 \beta(\mathrm{H})$ configuration places their maturity well below the onset of oil generation. This configuration is unstable and disappears during early thermal evolution of all sediments (ten Haven et al., 1986). The high proportions of moretane $17 \beta, 21 \alpha(>10 \%)$,

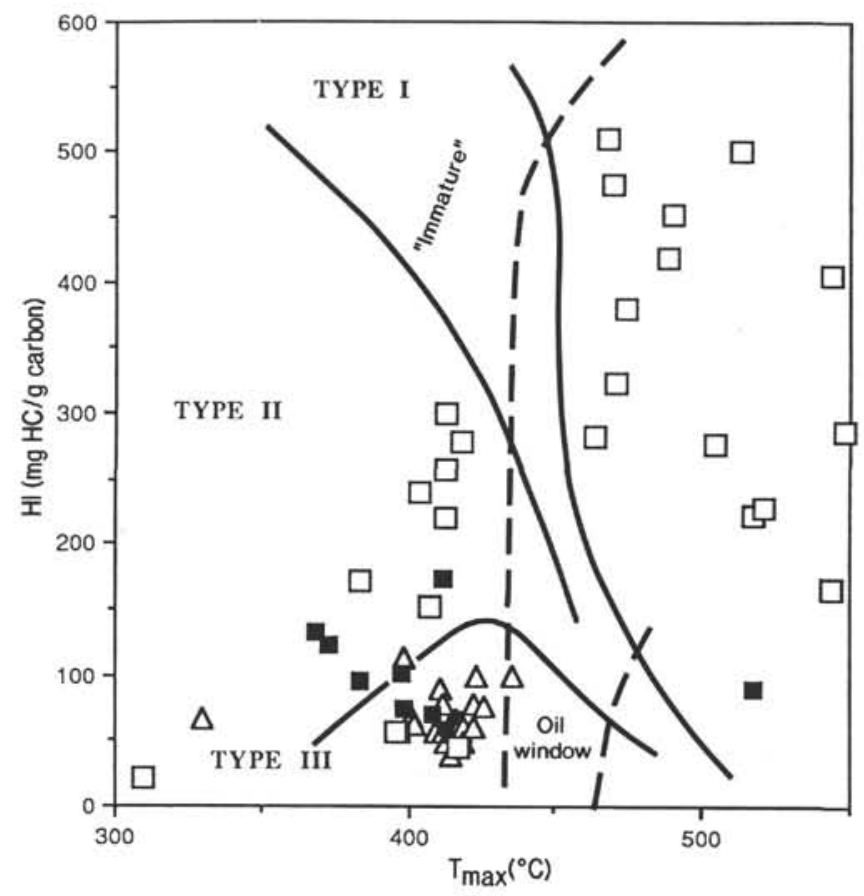

Figure 7. Plot of HI vs. $\mathrm{T}_{\max }$ for Site 765 Cenozoic samples (open squares), Site 765 Mesozoic samples (closed squares), and Site 766 Mesozoic samples (open triangles).

Table 6. Maturation-dependent biomarker parameters.

\begin{tabular}{|c|c|c|c|c|}
\hline $\begin{array}{l}\text { Core, section, } \\
\text { interval, }(\mathrm{cm})\end{array}$ & $\begin{array}{l}20 \mathrm{~S} \\
(\%)^{\mathrm{a}}\end{array}$ & $\begin{array}{l}22 \mathrm{~S} \\
(\%)^{\mathrm{b}}\end{array}$ & $\frac{\beta \alpha^{c}}{\alpha \beta}$ & $\begin{array}{c}T m^{\mathrm{d}} \\
T s\end{array}$ \\
\hline \multicolumn{5}{|l|}{$123-$} \\
\hline $765 C-44 R-5,2-10$ & 19 & 29 & 0.16 & 3.8 \\
\hline $765 C-49 R-1,96-104$ & 15 & 13 & 0.29 & 3.7 \\
\hline $766 \mathrm{~A}-38 \mathrm{R}-3,98-104$ & 14 & 38 & 0.11 & 0.9 \\
\hline $766 \mathrm{~A}-45 \mathrm{R}-4,98-106$ & 14 & 28 & 0.09 & 2.3 \\
\hline $766 A-47 R-4,95-102$ & 11 & 30 & 0.22 & 2.7 \\
\hline $766 \mathrm{~A}-48 \mathrm{R}-4,16-18$ & 16 & 36 & 0.17 & 1.6 \\
\hline $766 \mathrm{~A}-49 \mathrm{R}-3,47-51$ & 10 & 30 & 0.13 & 2.5 \\
\hline
\end{tabular}

compared to hopane $(17 \alpha, 21 \beta(\mathrm{H})$ (Table 6; Col. 3), and the dominance of $\mathrm{Tm}$ over the more stable Ts (Table 6; Col. 4) constitute further evidence of the immature nature of the sediments. The relative maturity within the sample set is harder to ascertain because these maturation parameters are also influenced to varying degrees by source effects. However, it appears that no significant maturity difference exists among samples from the two sites, although petrography of the organic matter (which was not done) might clarify the question of maturity.

\section{SUMMARY}

Examination of GC, GC-MS biomarker, and Rock-Eval data derived from samples analyzed at BMR and Rock-Eval data gathered aboard the Resolution indicates the following about the nature and source of organic matter at these two abyssal plain drill sites:

1. Cenozoic sediments from Site 766 have undetectable TOC $(<0.1 \mathrm{wt} \%)$. Cenozoic sediments from Argo have $<1.5 \mathrm{wt} \%$ TOC, 
and concentrations tend to decrease downhole (although erratically because of turbidite deposition) as organic carbon is remineralized via early diagenetic reactions.

2. Rock-Eval pyrolysis of Cenozoic samples from Argo suggests that the organic matter is mostly of a marine source, but with a component of reworked and degraded organic matter, probably derived from the continental margin via turbidite deposition.

3. Biomarker distributions determined by GC and GC-MS analysis indicate that the organic matter extracted from the sediments (inferred from the high relative abundances of the specific marine biomarker, 24-n-propylcholestane), at both sites, is primarily of a marine source with varying contributions of terrestrial organic matter (inferred from the ratios of $n-\mathrm{C}_{27 /} n-\mathrm{C}_{17}$ ).

4. Influxes of dinoflagellates, inferred from the high abundances of the 4-methylsteranes with the 23,24 dimethyl side chain, are significant at both sites.

5. The organic matter in the Lower Cretaceous sediments from both sites is immature. This immaturity and the low levels of extractable hydrocarbons found in these sediments suggest caution when interpreting biomarker data, which may not completely represent the total organic carbon content from the sediments.

6. Lower Cretaceous sediments from Argo are generally lean in organic matter, although a sample near the Barremian/Aptian boundary has a TOC of $5.1 \mathrm{wt} \%$ and samples near the Aptian/Albian boundary have TOC values up to $1.2 \mathrm{wt} \%$. Sediments from the Aptian and upper Barremian contain marine components of organic matter and relatively high proportions of terrestrial organic matter.

7. Lower Cretaceous sediments from Gascoyne have low TOC $(<0.1 \mathrm{wt} \%)$ in the Aptian/Albian and near the Barremian/Aptian boundaries. Maxima in TOC occur in the upper Barremian (1.02 $\mathrm{wt} \%)$, the Barremian/Hauterivian $(0.6 \mathrm{wt} \%)$, and the Valanginian $(1.8 \mathrm{wt} \%)$. Sediments from Site 766 contain marine organic matter, and samples from the upper Barremian contain higher amounts of terrestrial organic carbon than older sediments.

8. Influxes of bacteria comprise significant contributions to the organic matter composition at both sites.

\section{ACKNOWLEDGMENTS}

We thank Zoltan Horvath, Janet Hope, and Philip Fletcher for processing the samples, for assisting with the analyses, and for collating the data, and G. W. O'Brien, T. G. Powell, and L. Snowdon for their constructive comments. BMR Editor $\mathrm{K} . \mathrm{H}$. Wolf assisted with preparation of the final manuscript. DTH, CJB, and RES publish with the permission of the Executive Director, Bureau of Mineral Resources, Canberra, Australia.

\section{REFERENCES}

Bender, M. L., and Heggie, D. T., 1984. The fate of organic carbon on the seafloor: a status report. Geochem. Cosmochim. Acta., 48:977986.

Brassell, S. C., Eglinton, G., and Howell, V. J., 1987. Palaeoenvironmental assessment of marine organic-rich sediments using molecular organic geochemistry. In Brooks, J., and Fleet, A. J. (Eds.), Marine Petroleum Source Rocks. Geol. Soc. Spec. Publ., 26:79-98.

Boreham, C. J., and Powell, T. G., 1987. Sources and preservation of organic matter in the Cretaceous Toolebuc Formation, eastern Australia. Org. Geochem., 11:433-449.

Curiale, J. A., and Odermatt, J. R., 1989. Short-term biomarker variability in the Monterey Formation, Santa Maria Basin. Org. Geochem, 14:113.

Espitalie, J., Madec, M., and Tissot, B., 1980. Role of mineral matrix in kerogen pyrolysis: influence on petroleum generation and migration. AAPG Bull., 64:59-66.

Gough, M. A., and Rowland, S. J., 1990. Characterization of unresolved complex mixtures of hydrocarbons in petroleum. Nature, 344:648650 .
Grantham, P. J., Posthuma, J., and De Groot, K., 1980. Variation and significance of the $\mathrm{C}_{27}$ and $\mathrm{C}_{28}$ triterpane content of a North Sea core and various North Sea crude oils. In Maxwell, J. R., and Douglas, A. G. (Eds.), Advances in Organic Geochemistry (1979): Oxford (Pergamon Press), 29-38.

Grantham, P. J., 1986. The occurrence of unusual $\mathrm{C}_{27}$ and $\mathrm{C}_{29}$ sterane predominances in two types of Oman crude oil. Org. Geochem., $9: 1-10$.

Grantham, P. J., and Wakefield, L. L., 1988. Variations in the sterane carbon number distributions of marine source rock derived crude oils through geological time. Org. Geochem., 12:61-73.

Huang, M. Y., and Meinschien, W. G., 1979. Sterols as ecological indicators. Geochem. Cosmochim. Acta., 43:739-745.

Jackson, M. J., Powell, T. G., Summons, R. E., and Sweet, I. P., 1986. Hydrocarbon shows and petroleum source rocks in sediments as old as $1.7 \times 10^{9}$ years. Nature, 322:727-729.

Katz, B. J., 1983. Limitations of "Rock-Eval" pyrolysis for typing organic matter. Org. Geochem., 4:195-199.

Klomp, U. C., 1986. The chemical structure of a pronounced series of isoalkanes in South Oman crudes. In Leythaeuser, D., and Rullkötter, J. (Eds.), Advances in Organic Geochemistry (1985): Oxford (Pergamon Press), 807-814.

Ludden, J. N., Gradstein, F. M., et al., 1990. Proc. ODP. Init. Repts.,123: College Station, TX (Ocean Drilling Program).

Mackenzie, A. S., Brassell, S. C., Eglinton, G., and Maxwell, J. R., 1982. Chemical fossils; the geological fate of steroids. Science, 217:491504 .

Moldowan, J. M., Seifert, W. K., and Gallegos, E. J., 1985. Relationship between petroleum composition and depositional environment of petroleum source rocks. AAPG Bull., 69:1255-1268.

Moldowan, J. M., Fago, F. J., Lee, C. Y., Jacobson, S. R., Watt, D. S., Nacer-Eddine, S., Jeganathan, A., and Young, D. C., 1990. Sedimentary 24- $n$ propylcholestanes, molecular fossils diagnostic of marine algae. Science, 247:309-312.

Orr, W. L., 1983. Comments on pyrolytic hydrocarbon yields in SourceRock Evaluation. In Bjoroy, M., et al, (Eds.), Advances in Organic Geochemistry (1981): New York (Wiley), 775-782.

Ourisson, G., Rohmer, M., and Poralla, K.,1987. Prokaryotic hopanoids and other polyterpenoid sterol surrogates. Annu. Rev. Microbiol., 41:301-333.

Peters, K. E., 1986. Guidelines for evaluating petroleum source rock using programmed pyrolysis. AAPG Bull.., 32:318-329.

Powell, T. G., 1982. Petroleum geochemistry of the Verrill Canyon Formation: a source of Scotion shelf hydrocarbons. Bull. Can. Pet. Geol., 30:167-179.

1988. Pristante/phytane ratio as environmental indicator-discussion. Nature, 333:604.

Powell, T. G., and McKirdy, D. M., 1973. Relationship between ratio of pristane to phytane, crude oil composition and geological environment in Australia. Nature Phys. Sci., 243:37-39.

Price, P. L., J'Sullivan, T. O., and Alexander, R., 1988. The nature and occurrence of oil in Seram, Indonesia. Proc 16th Annu. Conv. Indonesian Pet. Assoc., Jakarta, 1987, 141-173.

Robinson, N., Eglinton, G., Brassell, S. C., and Cranwell, P. A., 1984. Dinoflagellate origin for sedimentary $4 \alpha$-methylsteroids and $5 \alpha(\mathrm{H})$ stanols. Nature, 308:439-442.

Rohmer, M., Bouvier-Nave, P., and Ourisson, G., 1984. Distribution of hopanoid triterpenes in prokaryotes. J. Gen. Microbiol., 130:11371150.

Rubinstein, I., and Albrecht, P., 1975. The occurrence of nuclear methylated steranes in a shale. J. Chem. Soc. Chem. Comm., 957-958.

Seifert, W. K., and Moldowan, J. M., 1978. Applications of steranes,terpanes and monoaromatics to the maturation, migration and source of crude oils. Geochem. Cosmochim. Acta., 42:77-95.

Shi, J., Mackenzie, A. S., Alexander, R., Eglinton, G., Gower, A. P. Wolff, G. A., and Maxwell, J. R., 1982. A biological marker investigation of petroleums and shales from the Shengli oilfield, the Peoples Republic of China. Chem. Geol, 35:1-31.

Summons, R. E., 1987. Branched alkanes from ancient and modern sediments: isomer discrimination by GC-MS with multiple reaction monitoring. Org. Geochem., 11:281-290.

Summons, R. E., and Capon, R. J., 1988. Fossil steranes with unprecedented methylation in ring-A. Geochim. Cosmochim. Acta, 53:27332736. 
Summons, R. E., and Jahnke, L. L., 1990. Identification of the methyhopanes in sediments and petroleums. Geochim. Cosmochim Acta, 54:247-251.

Summons, R. E., and Powell, T. G., 1987. Identification of aryl isoprenoids in source rocks and crude oils : Biological markers for the green sulphur bacteria. Geochem. Cosmochim. Acta., 51:557-566.

Summons, R. E., Powell, T. G., Boreham, C. J., 1988. Petroleum geology and geochemistry of the middle Proterozoic McArthur Basin, northern Australia. III Composition of extractable hydrocarbons. Geochim. Cosmochim. Acta, 52:1747-1763.

Summons, R. E., Volkman, J. K., Boreham, C. J., 1987. Dinosterane and other steroidal hydrocarbons of dinoflagellate origin in sediments and petroleum. Geochem. Cosmochim. Acta.,51: 3075-3082.

ten Haven, H. L., de Leeuw, J. W., and Schenck, P. A., 1985. Organic geochemical studies of a Messinian evaporitic basin, Northern Appennines (Italy). I:Hydrocarbon biological markers for a hypersaline environment. Geochem. Cosmochim. Acta., 49:2181-2191.

ten Haven, H. L., de Leeuw, J. W., Peakman, T. M., and Maxwell, J. R., 1986. Anomalies in steroid and hopanoid maturity indices. Geochem. Cosmochim. Acta., 50:853-855.

ten Haven, H. L., de Leeuw, J. W., Rullkötter, J., and Sinninghe Damste J. S., 1987. Restricted utility of the pristane to phytane ratio as a palaeoenvironmental indicator. Nature, 333:641-643. ten Haven, H. L., de Leeuw, J. W., Sinninghe Damste, J. S., Schenck, P. A., Palmer, S. E., and Zumberge, J. E., 1988. Application of biological markers in the recognition of palaeo hypersaline environments. In Fleet, A. J., Kelts, K., and Talbot, M. R., (Eds) Lacustrine Petroleum Source Rocks. Geol. Soc. Spec. Publ., 40:123-140.

Tissot, B. P., and Welte, D. H., 1984. Petroleum Formation and Occurrence: New York (Springer-Verlag).

Volkman, J. K., 1986. A review of sterol markers for marine and terrigenous organic matter. Org. Geochem., 9:83-99.

1988. Biological marker compounds as indicators of the depositional environments of petroleum source rocks. In Fleet, A. J., Kelts, K., and Talbot, M. R. (Eds.), Lacustrine Petroleum Source Rocks. Geol. Soc. Am. Spec. Publ., 40, 103-122.

Volkman, J. K., and Maxwell, J. R., 1986. Acyclic isoprenoids as biological markers. In Johns, R. B. (Ed.), Biological Markers in the Sedimentary Record: Amsterdam (Elsevier), 1-42.

Withers, N., 1983. Dinoflagellate sterols. In Scheuer P. J., (Ed.), Marine Natural Products. Chemical and Biological Perspectives, Vol. 5: New York (Academic Press), 87-130.

Date of initial receipt: 27 August 1990

Date of acceptance: 22 May 1991

Ms 123B-168 